Review

\title{
Dietary enrichment of eggs with omega-3 fatty acids: A review
}

\author{
Ilse Fraeye ${ }^{\mathrm{a}, *}$, Charlotte Bruneel ${ }^{\mathrm{a}}$, Charlotte Lemahieu ${ }^{\mathrm{a}}$, Johan Buyse ${ }^{\mathrm{b}}$, \\ Koenraad Muylaert ${ }^{\mathrm{c}}$, Imogen Foubert ${ }^{\mathrm{a}}$ \\ ${ }^{a}$ KU Leuven Campus Kortrijk (KULAK), Research Unit Food and Lipids, Department of Microbial and Molecular Systems, Leuven Food Science and Nutrition Research Centre (LFoRCe), \\ E. Sabbelaan 53, B-8500 Kortrijk, Belgium \\ ${ }^{\mathrm{b}}$ KU Leuven, Division of Livestock-Nutrition-Quality, Department of Biosystems, Kasteelpark Arenberg 30-bus 2456, B-3001 Heverlee, Belgium \\ c KU Leuven Campus Kortrijk (KULAK), Research Unit Aquatic Biology, E. Sabbelaan 53, B-8500 Kortrijk, Belgium
}

\section{A R T I C L E I N F O}

\section{Article history:}

Received 27 February 2012

Accepted 26 March 2012

Available online $\mathrm{xxxx}$

\section{Keywords:}

Omega-3 polyunsaturated fatty acids

Eggs

Flaxseed

Fish oil

Microalgae

\begin{abstract}
A B S T R A C T
The health benefits of omega- 3 polyunsaturated fatty acids ( $n-3$ PUFA) are generally recognized. Unfortunately, in most western countries, the recommended daily intake of these compounds is rarely met. Therefore, enrichment of commonly occurring foods can boost intake of these fatty acids. In this regard, eggs are an interesting target, as they form an integral part of the diet. Their $n-3$ PUFA profile can be modified through feed supplementation. A traditional $n-3$ PUFA source to be added to hens' diet is flaxseed, a plant source rich in $\alpha$-linolenic acid. Alternatively, hens are often fed fish oil, which is rich in long chain $n-3$ PUFA eicosapentaenoic acid (EPA) and docosahexaenoic acid (DHA). A more recent trend is feed supplementation with microalgae as a source of EPA and/or DHA. In this paper, recent scientific literature concerning $n-3$ PUFA enrichment in eggs is reviewed, giving an overview of advantages and disadvantages of the different approaches.
\end{abstract}

(c) 2012 Elsevier Ltd. All rights reserved.

\section{Contents}

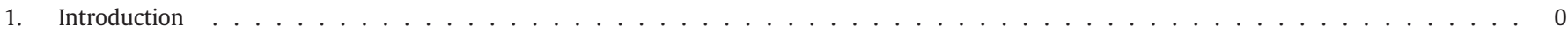

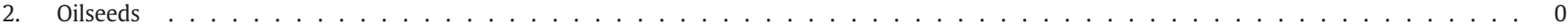

2.1. Production parameters and egg quality characteristics . . . . . . . . . . . . . . . . . . . . . . . . . 0

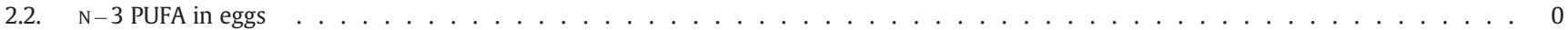

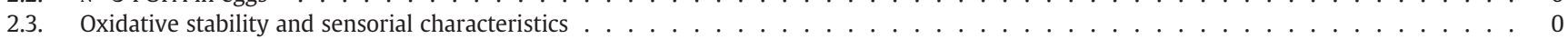

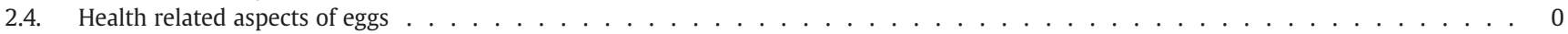

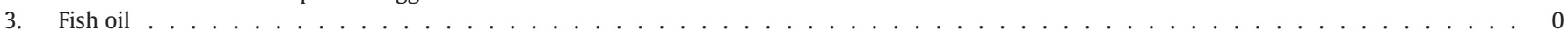

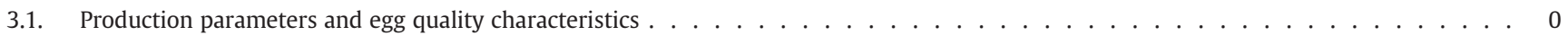

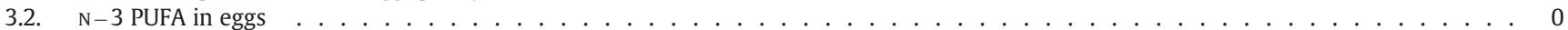

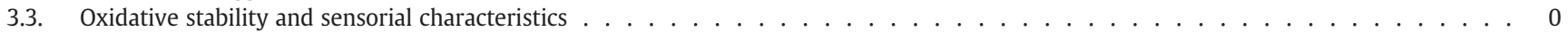

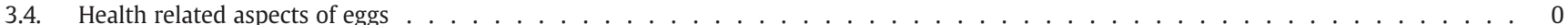

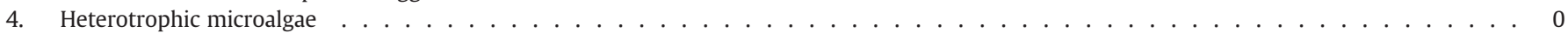

4.1. Production parameters and egg quality characteristics . . . . . . . . . . . . . . . . . . . . . . . . . . . 0

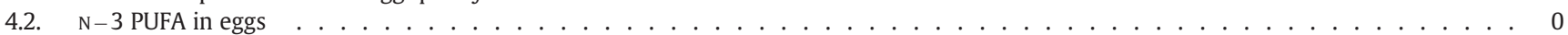

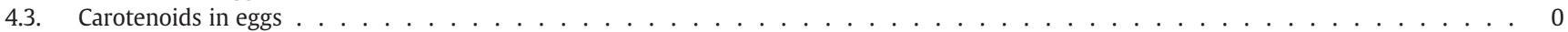

4.4. Oxidative stability and sensorial characteristics $\ldots \ldots \ldots \ldots \ldots$

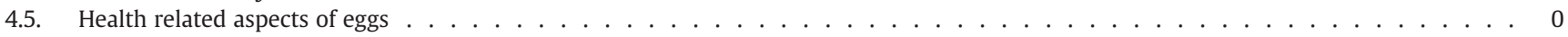

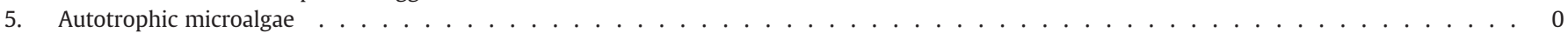

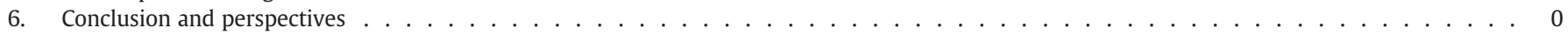

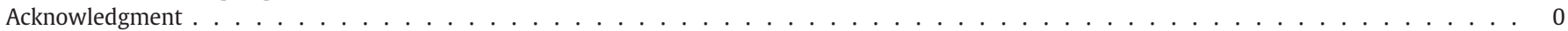

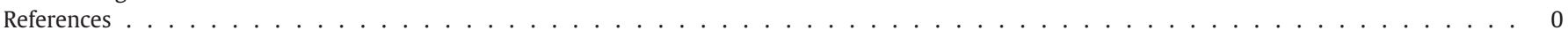

\footnotetext{
* Corresponding author. Tel.: + 32562460 41; fax: + 3256246997.
}

E-mail address: Ilse.fraeye@kuleuven-kulak.be (I. Fraeye). 


\section{Introduction}

It is generally accepted that omega- 3 polyunsaturated fatty acids ( $n-3$ PUFA) provide important health benefits to humans. The three major $n-3$ PUFA are $\alpha$-linolenic acid (18:3n-3, ALA) eicosapentaenoic acid (20:5 n-3, EPA) and docosahexaenoic acid (22:6n-3, DHA). The majority of the health benefits are related to EPA and DHA, rather than ALA (Trautwein, 2001). It has even been suggested that the principal biological role of ALA, which is an essential fatty acid, is to serve as a substrate for synthesis of long chain $n-3$ PUFA EPA and DHA (Burdge, 2004). In contrast, numerous health benefits have been attributed to EPA and DHA. They are mainly related to cardiovascular diseases, central nervous system and mental health diseases, and inflammation and immune functions.

The highest amount of scientific support is available for their protective effect with respect to cardiovascular diseases (Trautwein, 2001; Yashodhara et al., 2009). Although the effects have been debated to some extent rather recently (Kromhout, Giltay, \& Geleijnse, 2010), overall, the amount of evidence is substantive. This is reflected in the approval of an EFSA claim, stating that a cause and effect relationship has been established between the consumption of EPA and DHA and maintenance of normal cardiac function (European Food Safety European Food Safety Authority, 2010). Although it is welldocumented that both EPA and DHA exert a protective effect, there are indications that the importance of DHA towards some specific cardiovascular risk factors is higher than that of EPA. Further research is however needed to clarify these differential effects (Cottin, Sanders, \& Hall, 2011).

A second well-documented bioactive role, which can be specifically attributed to DHA, is its importance for the development of brain, retinal and neural tissues in fetuses and young children. As a result, adequate DHA intake in pregnant and nursing woman is important (Jordan, 2010).

In addition, $n-3$ PUFA have been reported to play a role in prevention and treatment of many other chronic diseases, such as neurological disorders, cancer, inflammatory diseases, obesity and diabetes mellitus (Trautwein, 2001; Yashodhara et al., 2009). Further research is needed to substantiate these effects.

In humans, ALA is converted into EPA by removal of a hydrogen atom by $\Delta$-6-desaturase, followed by addition of two carbons by an elongase, as presented in Fig. 1. A different process of desaturation and elongation results in formation of DHA. Unfortunately, conversion of ALA into EPA is limited, and further transformation to DHA is even lower. This is caused by competition for the enzymes involved. Although ALA is the preferred substrate for $\Delta$-6-desaturase, the enzyme also acts on linoleic acid (18:2n-6, LA) (Burdge, 2004; Trautwein, 2001). This competition causes the efficiency of ALA conversion into EPA and DHA to decrease as the ratio LA/ALA increases (and vice versa). In western countries, the current intake of LA and other $n-6$ PUFA is rather high relative to $n-3$ PUFA, which suppresses ALA conversion.

Considering the fact that EPA and DHA have important physiological functions, and that their in vivo synthesis from ALA is limited, dietary intake of these long chain n-3 PUFA is indispensable. Today, various governments and health organizations recommend dietary intakes for total $\mathrm{n}-3$ PUFA of 1.4 to $2.5 \mathrm{~g} / \mathrm{d}$, with EPA plus DHA ranging from 140 to $600 \mathrm{mg} / \mathrm{d}$ (Molendi-Coste, Legry, \& Leclercq, 2011). Harris et al. (2009) stated that a Dietary Reference Intake of 250 to $500 \mathrm{mg} / \mathrm{d}$ $\mathrm{EPA}+\mathrm{DHA}$ should be recommended in order to decrease the risk of coronary heart disease, based on the current scientific evidence available.

Unfortunately, in many western countries, these recommendations are not met by the majority of consumers (Sioen et al., 2006). Fish is the richest dietary source of EPA and DHA, but a large part of the population consumes little or no fish (Welch, Shakya-Shrestha, Lentjes, Wareham, \& Khaw, 2011). In addition, declining fish stocks, as well as the presence
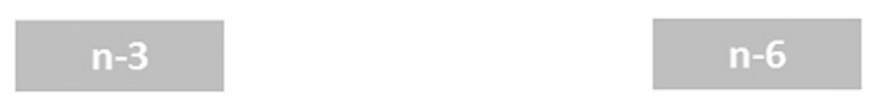

18:3 ALA

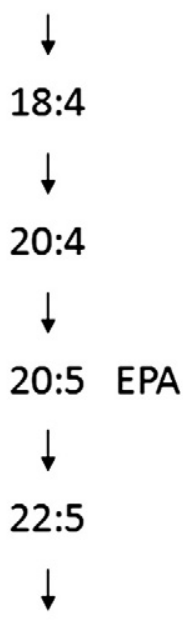

24:5

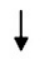

$24: 6$

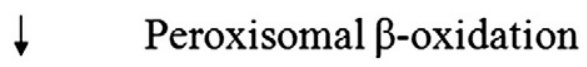

\section{2:6 DHA}

Fig. 1. Metabolism of $n-3$ and $n-6$ PUFA.

of pollutants such as heavy metals and PCBs in fish (Domingo \& Bocio, 2007; Qi et al., 2004) may compromise consumption of fish as the major source of EPA and DHA. Therefore, other dietary sources of EPA and DHA are being sought. Food enrichment is probably the best long-term solution to boost intake of long chain $n-3$ PUFA (Molendi-Coste et al., 2011). An interesting route is $n-3$ PUFA enrichment of eggs through dietary supplementation of laying hens. An important advantage of this approach, is their wide acceptability as human food and food ingredient. They are consumed worldwide, without restriction by any religious or cultural consideration. Typically, the amount of saturated or monounsaturated fatty acids in eggs is hardly influenced by the lipids in the feed (Baucells, Crespo, Barroeta, Lopez-Ferrer, \& Grashorn, 2000; Cachaldora, Garia-Rebollar, Alvarez, Mendez, \& De Blas, 2008; Herber \& Van Elswyk, 1996; Van Elswyk, Dawson, \& Sams, 1995). In contrast, the PUFA content and profile in the egg can be modified through dietary supplementation.

In this literature review, different approaches towards enrichment of hen eggs with $n-3$ PUFA are discussed. Numerous studies have been published on hen dietary supplementation with ALA rich seeds or oil, or EPA/DHA-rich fish oil. More recently, use of microalgae as a source of EPA and/or DHA is being explored. For each of these approaches, the influence on hens' production parameters, egg quality characteristics and $n-3$ PUFA deposition in eggs are discussed. In addition, oxidative stability and sensorial characteristics of eggs are reviewed. Also, health-related aspects of consumption of such eggs are pointed out. As such, this review provides an overview of advantages and disadvantages of the different approaches. To the best of our knowledge, there is no recent literature review available covering the latest developments in this field. 


\section{Oilseeds}

ALA is produced by various plants, such as canola, soybean, walnuts and flaxseed, the latter being one of the most concentrated sources of ALA (Harris et al., 2009). Over the past 20 years, the influence of dietary supplementation with flaxseed or flaxseed oil on hens' performance and egg characteristics has been studied extensively. Since the late nineties, $\mathrm{n}-3$ PUFA enriched eggs produced through feed supplementation with flaxseed have become available on the market in many countries (Surai \& Sparks, 2001).

\subsection{Production parameters and egg quality characteristics}

Reports on production parameters and egg characteristics (such as feed intake, egg production, egg weight, percentage yolk, ...) of hens fed flaxseed are very contradictory. For example, feed consumption has been reported to decrease (Aymond \& Van Elswyk, 1995; Hayat, Cherian, Pasha, Khattak, \& Jabbar, 2009) or increase (Caston, Squires, \& Leeson, 1994) upon flaxseed supplementation. Several authors report a decrease in egg weight (Caston et al., 1994; Scheideler \& Froning, 1996), while other authors observed no change (Aymond \& Van Elswyk, 1995; Bean \& Leeson, 2003; Jiang, Ahn, \& Sim, 1991) or even an increase (Rizzi, Bochicchio, Bargellini, Parazza, \& Simioli, 2009). Egg production has been reported to decrease (Aymond \& Van Elswyk, 1995), remain unchanged (Bean \& Leeson, 2003; Caston et al., 1994; Jiang et al., 1991) or increase (Scheideler \& Froning, 1996) in response to flaxseed supplementation.

An unequivocal explanation for these differences cannot be proposed, but they can probably be ascribed to differences in experimental setup. Hen's age and strain are known to have an influence on production parameters (Scheideler, Jaroni, \& Froning, 1998), but to date, there is no study available which specifically compares the performance of hens of differential age and/or strain following $n-3$ PUFA supplementation. In addition, differences in basal diet composition may in part explain the contradicting outcomes (Gonzalez-Esquerra \& Leeson, 2001). Furthermore, feed formulation is thought to be a major factor. Most authors did not formulate experimental feeds under comparison isocalorically, and even if they intended to do so, formulation was based on calculated energy values. Caston et al. (1994) studied the apparent metabolizable energy of diets supplemented with flaxseed and found that hens inefficiently digested these diets. As a result, the apparent metabolizable energy of supplemented diets was lower than that of the basal diet. A laxative effect of flaxseed and an increased rate of passage have been reported by Scheideler and Froning (1996). Anti-nutritional factors in flaxseed may impair digestion and absorption of energy yielding nutrients (Bean \& Leeson, 2003). This may explain decreased egg production or egg weight in several studies. Bean and Leeson (2002) found that extrusion of the flaxseed in order to eliminate anti-nutritional factors, resulted in an increase in apparent metabolizable energy. Such pretreatment may therefore improve production parameters, although this has not been specifically studied.

\section{2. $N-3$ PUFA in eggs}

Table 1 summarizes data on egg $n-3$ PUFA content from 26 publications in which dietary supplementation with various sources of n-3 PUFA was studied. From a number of studies presented here (Aymond \& Van Elswyk, 1995; Ferrier et al., 1995; Scheideler \& Froning, 1996), it can be concluded that when flaxseed is added to hens' feed, yolk ALA levels increase proportional to the percentage of flaxseed addition. Furthermore, amounts of DHA in yolk increase as well, albeit to a lesser extent, and not in linear response to the level of flaxseed. Amounts of EPA hardly increase (Aymond \& Van Elswyk, 1995; Bean \& Leeson, 2003; Ferrier et al., 1995; Poureslami, Raes, Huyghebaert, Batal, \& De Smet, 2012; Scheideler \& Froning, 1996). For example, when Aymond and Van Elswyk (1995) fed 15\% of ground flaxseed to hens, the
ALA content of the eggs increased from 13 to $212 \mathrm{mg} / \mathrm{egg}$, while DHA increased from 28 to $90 \mathrm{mg} / \mathrm{egg}$. This indicates that hens are able to convert ALA into DHA. Most authors report that the conversion is rather limited, similar as in humans (Aymond \& Van Elswyk, 1995). This is caused by the low activity of desaturase enzymes involved in conversion of ALA. However, the conversion efficiency is affected by several factors. First of all, the presence of high amounts of $n-6$ PUFA in the diet increases the competition for the desaturase enzymes, causing a decrease in ALA conversion efficiency (see Fig. 1) (Cachaldora, Garcia-Rebollar, Alvarez, De Blas, \& Mendez, 2008). As a consequence, the $n-6 / n-3$ ratio of the diet is one of the major influencing factors. Secondly, addition of antioxidants such as vitamin $\mathrm{E}$ also seems to modulate the elongationdesaturation pathway in a favorable way (Hayat, Cherian, Pasha, Khattak, \& Jabbar, 2010a; Hayat et al., 2009). Thirdly, Fredriksson, Elwinger, and Pickova (2006) estimated that hens' age and strain have an effect on the efficiency of ALA elongation and desaturation. It has been postulated that older hens have a larger liver, allowing a more effective conversion of ALA into DHA. Finally, Cachaldora, Garia-Rebollar, Alvarez, Mendez, and De Blas (2008) studied eggs from hens fed diets rich in both ALA and EPA/DHA (e.g. flaxseed + fish oil) and observed that an excess of the latter long-chain fatty acids limited the conversion of ALA. They concluded that the conversion efficiency depends mainly on the total amount of $n-3$ PUFA in the diet, as well as on their relative proportions. It is also interesting to point out that the ALA bioconversion in female birds seems to be higher than in male birds, as was pointed out in a recent study on broiler chickens. This may relate to differences in steroid hormones and/or other sex-related differences in metabolism (Poureslami, Raes, Turchini, Huyghebaert, \& De Smet, 2010).

The increase in amounts of $n-3$ PUFA in the egg yolk was paralleled by a decrease in $n-6$ PUFA, especially arachidonic acid (20:4 n-6, AA) (Bean \& Leeson, 2003; Hayat et al., 2009; Jiang et al., 1991), which also relates to competition for the desaturase enzyme needed for conversion of ALA into EPA, as well as conversion of LA into AA (see Fig. 1). In addition, it has been suggested that $n-3$ PUFA are preferentially incorporated into biological membranes at the expense of $n-6$ PUFA (Herber \& Van Elswyk, 1996). The egg yolk cholesterol content is not influenced by flaxseed supplementation (Hayat et al., 2009; Scheideler \& Froning, 1996).

In the following text, these eggs will be referred to as "ALA-enriched eggs".

\subsection{Oxidative stability and sensorial characteristics}

$n-3$ PUFA are susceptible to oxidation. Therefore, increasing the level of these sensitive fatty acids in egg yolk may bring about a higher extent of lipid oxidation, which could impair sensorial quality. Furthermore, lipid oxidation products can damage biological tissues and have been related to several diseases such as cancer and atherosclerosis (Aymond \& Van Elswyk, 1995). There are indications of increased thiobarbituric acid reactive substance deposition in eggs following addition of flaxseed to hens' diet (Hayat et al., 2010a), although other authors did not observe any differences compared to control eggs (Aymond \& Van Elswyk, 1995). Any oxidative damage in egg yolks results from direct deposition of oxidized lipids from the feed, lipids are not further oxidized during storage (Galobart, Barroeta, Baucells, Cortinas, \& Guardiola, 2001; Hayat et al., 2010a). As a result, observed differences in oxidative stability of yolk lipids may relate to quality and storage conditions of the flaxseed.

At levels of at least $10 \%$ of flaxseed addition, consumer panels perceived "fishy" off-flavors (Caston et al., 1994; Leeson, Caston, \& MacLaurin, 1998) and concluded that eggs were less acceptable (Scheideler, Froning, \& Cuppett, 1997). A number of studies have investigated the effect of antioxidants (e.g. vitamin E) supplementation in combination with flaxseed, in order to enhance egg lipid stability. Unfortunately, in most studies, no significant improvement in lipid stability and/or sensorial characteristics was noted (Hayat, 
Table 1

Overview of studies in which egg lipid composition was analyzed following feed enrichment with different sources of $n-3$ PUFA.

\begin{tabular}{|c|c|c|c|c|}
\hline \multirow[t]{2}{*}{ Reference } & \multirow[t]{2}{*}{ Diet } & \multicolumn{3}{|c|}{ Egg lipid composition } \\
\hline & & ALA & EPA & DHA \\
\hline & & \multicolumn{3}{|l|}{ mg/egg } \\
\hline \multirow{7}{*}{$\begin{array}{l}\text { Aymond and Van } \\
\text { Elswyk (1995) }\end{array}$} & Control & 13 & 25 & 28 \\
\hline & $1.5 \%$ menhaden oil & 18 & 15 & 83 \\
\hline & $5 \%$ whole flax & 90 & 3.3 & 68 \\
\hline & $5 \%$ ground flax & 110 & 5.3 & 68 \\
\hline & $15 \%$ whole flax & 163 & 7.6 & 73 \\
\hline & $15 \%$ ground flax & 212 & 20 & 90 \\
\hline & & \multicolumn{3}{|c|}{$\%$ of total FA } \\
\hline \multirow[t]{3}{*}{ Baucells et al. (2000) } & $4 \%$ fish oil & 0.44 & 0.92 & 3.18 \\
\hline & e.g.: $4 \%$ linseed oil & 4.87 & 0.25 & 1.56 \\
\hline & & \multicolumn{3}{|c|}{$\mathrm{mg} / 50 \mathrm{~g} \mathrm{egg}$} \\
\hline \multirow[t]{3}{*}{ Bean and Leeson (2003) } & Control & 38.5 & & 53.3 \\
\hline & $10 \%$ flaxseed & 306.3 & & 83.7 \\
\hline & & \multicolumn{3}{|c|}{$\%$ of total FA } \\
\hline \multirow[t]{3}{*}{ Bovet et al. (2007) } & Control (incl. fish meal) & 0.47 & 0.04 & 0.39 \\
\hline & Fish oil & 1.26 & 0.4 & 5.41 \\
\hline & & \multicolumn{3}{|c|}{$\%$ of total FA } \\
\hline \multirow[t]{4}{*}{ Cachaldora et al. (2005) } & Control: $1.7 \%$ marine fish oil & 0.355 & 0.135 & 3.15 \\
\hline & $0.77 \% \mathrm{HMA}^{\mathrm{a}}$ oil & 0.371 & 0.110 & 2.75 \\
\hline & $1.7 \% \mathrm{HMA}^{\mathrm{a}}$ oil & 0.392 & 0.197 & 3.69 \\
\hline & & \multicolumn{3}{|c|}{$\%$ of total FA } \\
\hline \multirow{10}{*}{$\begin{array}{l}\text { Cachaldora, Garia-Rebollar, } \\
\text { Alvarez, Mendez, and } \\
\text { De Blas (2008) }\end{array}$} & $\begin{array}{l}\mathrm{CLA}^{\mathrm{b}}+\mathrm{HOSO}^{\mathrm{c}}+\text { EPA-rich } \\
\text { fish oil }(2.9 \mathrm{~g} \mathrm{n}-3 \text { PUFA } / \mathrm{kg})\end{array}$ & 0.25 & 0.16 & 2.70 \\
\hline & $\begin{array}{l}\mathrm{CLA}^{\mathrm{b}}+\mathrm{HOSO}^{\mathrm{c}}+\text { DHA-rich } \\
\text { fish oil }(2.9 \mathrm{~g} \mathrm{n}-3 \text { PUFA } / \mathrm{kg})\end{array}$ & 0.20 & 0.09 & 2.96 \\
\hline & $\begin{array}{l}\mathrm{CLA}^{\mathrm{b}}+\mathrm{HOSO}^{\mathrm{c}}+\text { OIL from } \\
\mathrm{HMA}^{\mathrm{a}}(2.9 \mathrm{~g} \mathrm{n}-3 \text { PUFA } / \mathrm{kg})\end{array}$ & 0.21 & 0.05 & 3.37 \\
\hline & $\begin{array}{l}\mathrm{CLA}^{\mathrm{b}}+\mathrm{HOSO}^{\mathrm{c}}+\mathrm{EPA}^{-\mathrm{rich}} \\
\text { fish oil }(3.7 \mathrm{~g} \mathrm{n}-3 \text { PUFA } / \mathrm{kg})\end{array}$ & 0.24 & 0.23 & 2.81 \\
\hline & $\begin{array}{l}\mathrm{CLA}^{\mathrm{b}}+\mathrm{HOSO}^{\mathrm{c}}+\text { DHA-rich } \\
\text { fish oil }(3.7 \mathrm{~g} \mathrm{n}-3 \text { PUFA } / \mathrm{kg})\end{array}$ & 0.20 & 0.10 & 3.44 \\
\hline & $\begin{array}{l}\mathrm{CLA}^{\mathrm{b}}+\mathrm{HOSO}^{\mathrm{c}}+\text { OIL from } \\
\mathrm{HMA}^{\mathrm{a}}(3.7 \mathrm{~g} \mathrm{n}-3 \text { PUFA } / \mathrm{kg})\end{array}$ & 0.22 & 0.06 & 3.92 \\
\hline & $\begin{array}{l}\mathrm{CLA}^{\mathrm{b}}+\mathrm{HOSO}^{\mathrm{c}}+\text { EPA-rich } \\
\text { fish oil }(4.5 \mathrm{~g} \mathrm{n}-3 \mathrm{PUFA} / \mathrm{kg})\end{array}$ & 0.23 & 0.21 & 3.15 \\
\hline & $\begin{array}{l}\mathrm{CLA}^{\mathrm{b}}+\mathrm{HOSO}^{\mathrm{c}}+\text { DHA-rich } \\
\text { fish oil }(4.5 \mathrm{~g} \mathrm{n}-3 \mathrm{PUFA} / \mathrm{kg})\end{array}$ & 0.20 & 0.12 & 3.49 \\
\hline & $\begin{array}{l}\mathrm{CLA}^{\mathrm{b}}+\mathrm{HOSO}^{\mathrm{c}}+\text { OIL from } \\
\mathrm{HMA}^{\mathrm{a}}(4.5 \mathrm{~g} \mathrm{n}-3 \text { PUFA } / \mathrm{kg})\end{array}$ & 0.23 & 0.08 & 4.10 \\
\hline & & \multicolumn{3}{|c|}{$\%$ of total FA } \\
\hline \multirow[t]{7}{*}{ Carrillo et al. (2008) } & Control & 1.21 & 0.03 & 2.18 \\
\hline & $2 \%$ sardine oil $+10 \%$ & 0.78 & 1.52 & 9.60 \\
\hline & $2 \%$ sardine oil $+10 \%$ & 0.76 & 1.4 & 8.76 \\
\hline & Sargassum sinicola & & & \\
\hline & $2 \%$ sardine oil $+10 \%$ & 0.73 & 1.11 & 8.55 \\
\hline & Enteromorpha spp & & & \\
\hline & & \multicolumn{3}{|c|}{$\%$ of total FA } \\
\hline \multirow[t]{4}{*}{ Cheng et al. (2004) } & Control ( $2 \%$ butter) & 0.4 & 0.1 & 0.6 \\
\hline & $0.5 \% \mathrm{HMA}^{\mathrm{a}}$ oil ( $1.5 \%$ butter) & 0.4 & 0.1 & 1.8 \\
\hline & $2 \% \mathrm{HMA}^{\mathrm{a}}$ oil & 0.5 & 0.2 & 3.1 \\
\hline & & \multicolumn{3}{|c|}{$\%$ of total FA } \\
\hline Cherian and Sim (1996) & Control & 1.1 & 0.0 & 1.2 \\
\hline & Flax oil & 9.3 & 0.2 & 2.1 \\
\hline & & $\%$ of tota & IFA & \\
\hline Farrell (1998) & Control (sunflower oil) & 0.20 & 0.20 & 0.44 \\
\hline & $5 \%$ fish oil & 0.36 & 1.00 & 5.27 \\
\hline & $3 \%$ fish oil $+1 \%$ linseed oil & 2.26 & 0.58 & 3.80 \\
\hline & $\begin{array}{l}2 \% \text { fish oil }+1 \% \text { linseed oil }+ \\
1 \% \text { canola oil }\end{array}$ & 2.32 & 0.45 & 3.38 \\
\hline & & $\%$ of tota & FA & \\
\hline Ferrier et al. (1992) & Control & 0.3 & Trace & 0.2 \\
\hline & $20 \%$ ground flaxseed & 8.2 & Trace & 0.7 \\
\hline
\end{tabular}

Table 1 (continued)

\begin{tabular}{|c|c|c|c|c|}
\hline \multirow[t]{2}{*}{ Reference } & \multirow[t]{2}{*}{ Diet } & \multicolumn{3}{|c|}{ Egg lipid composition } \\
\hline & & ALA & EPA & DHA \\
\hline & & \multicolumn{3}{|c|}{$\%$ of total FA } \\
\hline \multirow[t]{5}{*}{ Ferrier et al. (1995) } & Control & 0.5 & 0.1 & 1.0 \\
\hline & $10 \%$ flaxseed & 5.5 & 0.2 & 1.7 \\
\hline & $20 \%$ flaxseed & 10.7 & 0.2 & 1.8 \\
\hline & & \multicolumn{3}{|c|}{$\%$ of total FA } \\
\hline & & \multicolumn{3}{|c|}{ Phospholipids } \\
\hline \multirow{12}{*}{$\begin{array}{l}\text { Fredriksson et al. } \\
\quad(2006)\end{array}$} & Rapeseed oil control & 0.5 & 0.1 & 6.5 \\
\hline & $\begin{array}{l}\text { Rapeseed oil control }+10 \% \\
\text { N. oculata }\end{array}$ & 0.4 & 0.3 & 6.9 \\
\hline & $\begin{array}{l}\text { Rapeseed oil control }+20 \% \\
\text { N. oculata }\end{array}$ & 0.4 & 0.5 & 7.4 \\
\hline & Corn-rapeseed oil control & 0.3 & $<$ d.l. & 5.1 \\
\hline & $\begin{array}{l}\text { Corn-rapeseed oil control + } \\
10 \% \text { N. oculata }\end{array}$ & 0.2 & 0.2 & 5.8 \\
\hline & & \multicolumn{3}{|c|}{ Triacylglycerols } \\
\hline & Rapeseed oil control & 2.1 & 0.1 & 0.3 \\
\hline & $\begin{array}{l}\text { Rapeseed oil control }+10 \% \\
\text { N. oculata }\end{array}$ & 2.4 & 0.1 & 0.3 \\
\hline & $\begin{array}{l}\text { Rapeseed oil control }+20 \% \\
\text { N. oculata }\end{array}$ & 2.5 & 0.1 & 0.3 \\
\hline & $\begin{array}{l}\text { Corn-rapeseed oil } \\
\text { control }\end{array}$ & 1.4 & 0.02 & 0.2 \\
\hline & $\begin{array}{l}\text { Corn-rapeseed oil control + } \\
10 \% \text { N. oculata }\end{array}$ & 1.4 & 0.06 & 0.2 \\
\hline & & \multicolumn{3}{|l|}{ mg/egg } \\
\hline \multirow[t]{4}{*}{ Foubert et al. (2011) } & Control & 19.7 & $<$ d.l. & 25.1 \\
\hline & $5 \%$ N. gaditana & 15.9 & 2.3 & 44.9 \\
\hline & $10 \%$ N. gaditana & 17.0 & 4.7 & 50.4 \\
\hline & & \multicolumn{3}{|c|}{ mg/50 g egg } \\
\hline \multirow[t]{3}{*}{ Gillingham et al. (2005) } & Control & 15.6 & 0.6 & 30.6 \\
\hline & Fish oil + ground flaxseed & 173.9 & 16.9 & 108.4 \\
\hline & & \multicolumn{3}{|c|}{$\mathrm{mg} / 50 \mathrm{~g}$ egg } \\
\hline \multirow{8}{*}{$\begin{array}{l}\text { Gonzalez-Esquerra and } \\
\text { Leeson (2000) }\end{array}$} & Control & 26 & 0 & 26 \\
\hline & $\begin{array}{l}2 \% \text { deodorized } \\
\text { menhaden oil }\end{array}$ & 26 & 13 & 85 \\
\hline & $\begin{array}{l}4 \% \text { deodorized } \\
\text { menhaden oil }\end{array}$ & 38 & 31 & 123 \\
\hline & $\begin{array}{l}6 \% \text { deodorized } \\
\text { menhaden oil }\end{array}$ & 58 & 61 & 196 \\
\hline & $2 \%$ regular menhaden oil & 23 & 16 & 87 \\
\hline & $4 \%$ regular menhaden oil & 30 & 30 & 114 \\
\hline & $6 \%$ regular menhaden oil & 37 & 45 & 144 \\
\hline & & \multicolumn{3}{|c|}{$\%$ of total FA } \\
\hline \multirow[t]{9}{*}{ Hayat et al. (2009) } & Control & 0.1 & 0.00 & 2.07 \\
\hline & $10 \%$ flax & 1.05 & 0.00 & 3.75 \\
\hline & $\begin{array}{l}10 \% \text { flax }+50 \mathrm{IU} \\
\alpha \text {-tocopherol }\end{array}$ & 1.4 & 0.00 & 4.28 \\
\hline & $\begin{array}{l}10 \% \text { flax }+100 \mathrm{IU} \\
\alpha \text {-tocopherol }\end{array}$ & 1.56 & 0.05 & 4.41 \\
\hline & $\begin{array}{l}10 \% \text { flax }+150 \mathrm{IU} \\
\alpha \text {-tocopherol }\end{array}$ & 1.42 & 0.08 & 3.83 \\
\hline & $10 \%$ flax $+50 \mathrm{mg} / \mathrm{kg} \mathrm{BHT}{ }^{\mathrm{d}}$ & 2.05 & 0.05 & 5.37 \\
\hline & $10 \%$ flax $+100 \mathrm{mg} / \mathrm{kg} \mathrm{BHT}{ }^{\mathrm{d}}$ & 1.27 & 0.05 & 4.32 \\
\hline & $10 \%$ flax $+150 \mathrm{mg} / \mathrm{kg} \mathrm{BHT}$ & 1.82 & 0.00 & 4.85 \\
\hline & & \multicolumn{3}{|c|}{ mg/g yolk } \\
\hline \multirow{5}{*}{$\begin{array}{l}\text { Herber and Van Elswyk } \\
\text { (1996) }\end{array}$} & Control & & & 2.3 \\
\hline & $\begin{array}{l}1.5 \% \text { menhaden oil } \\
(\mathrm{EPA}+\mathrm{DHA})\end{array}$ & & & 8.1 \\
\hline & $2.4 \% \mathrm{HMA}^{\mathrm{a}}$ & & & 8.8 \\
\hline & $4.8 \% \mathrm{HMA}^{\mathrm{a}}$ & & & 11.5 \\
\hline & & mg/egg & & \\
\hline \multirow[t]{4}{*}{ Lawlor et al. (2010) } & Control & 70 & 1 & 62 \\
\hline & $\begin{array}{l}2 \% \text { microencapsulated } \\
\text { fish oil }\end{array}$ & 65 & 12 & 96 \\
\hline & $\begin{array}{l}4 \% \text { microencapsulated } \\
\text { fish oil }\end{array}$ & 73 & 24 & 129 \\
\hline & $\begin{array}{l}6 \% \text { microencapsulated } \\
\text { fish oil }\end{array}$ & 70 & 40 & 162 \\
\hline
\end{tabular}


Table 1 (continued)

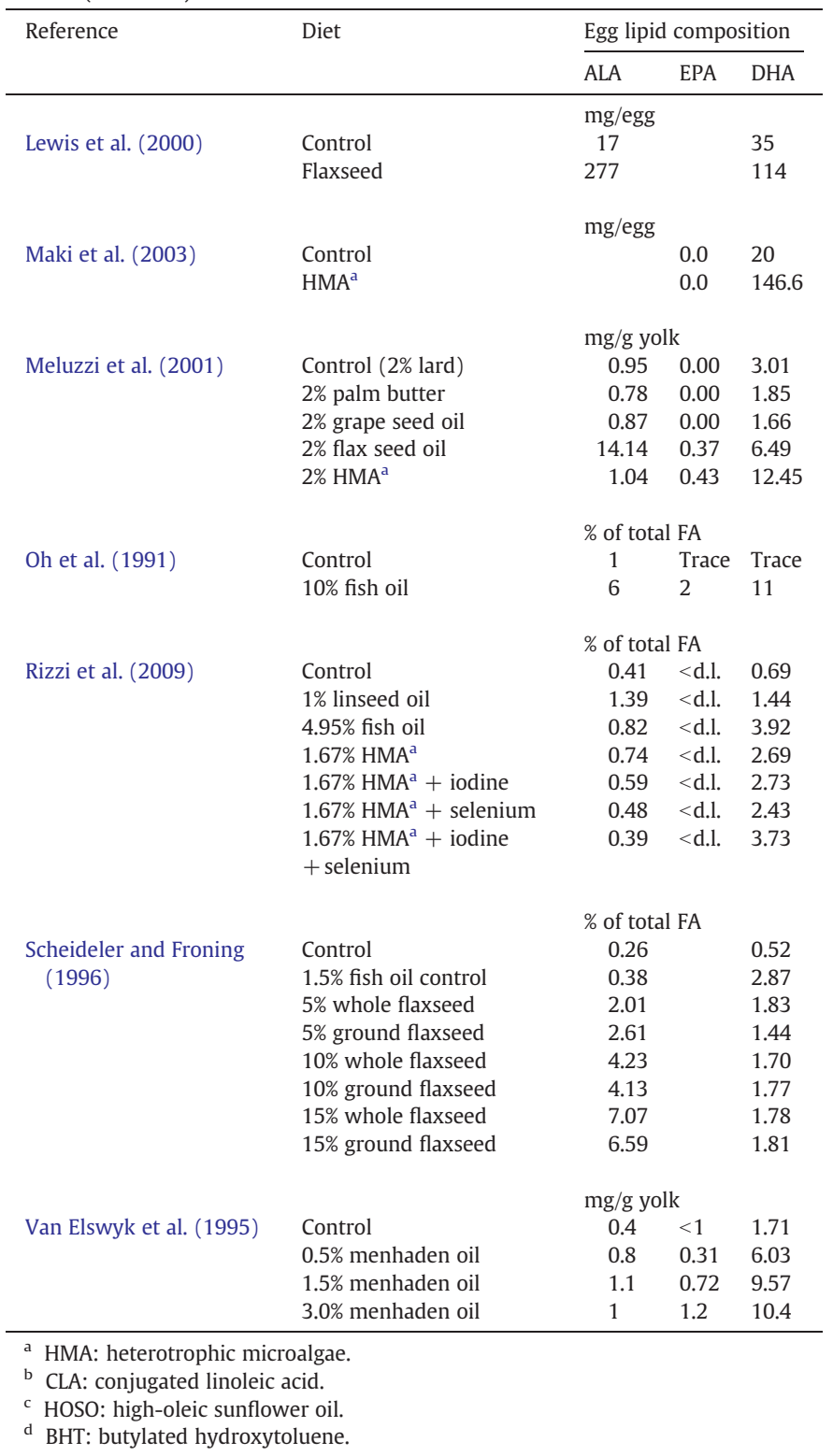

Cherian, Pasha, Khattak, \& Jabbar, 2010b; Hayat et al., 2010a; Leeson et al., 1998).

\subsection{Health related aspects of eggs}

To date, no long-term clinical studies have been performed which aimed at establishing a direct relationship between intake of ALAenriched eggs and incidence of (cardiovascular) diseases. However, several studies have been able to demonstrate that $n-3$ PUFA in eggs are taken up by the human digestive tract and that they are transferred to blood plasma where they can exert their bioactive role.

Ferrier et al. (1992) studied serum and platelet lipid profiles of 5 healthy volunteers who weekly consumed 28 ALA-enriched eggs. Within a week, serum triglyceride levels (a significant predictor of coronary heart disease) declined by $35 \%$. A similar observation was made by Jiang and Sim (1993) who weekly fed 14 ALA-enriched eggs to healthy volunteers during 18 days, as well as by Lewis, Schalch, and Scheideler (2000) upon feeding 14 ALA-enriched eggs per week to hypercholesterolemic humans for 6 weeks. In contrast, no decrease in serum triglyceride level upon weekly consumption of 28 ALA-enriched eggs was observed in a second study of Ferrier et al. (1995), in which more subjects (28) were examined than in their preliminary study (Ferrier et al., 1992), and which had a better controlled experimental setup. In addition, Cherian and $\operatorname{Sim}$ (1996) also perceived no change in serum triglyceride level of 8 nursing women upon weekly consumption of 14 ALA-enriched eggs.

Daily consumption of 4 ALA-enriched eggs by healthy volunteers resulted in enrichment of platelet phospholipids in DHA, which may reduce platelet aggregation. In contrast, platelet phospholipid ALA levels remained extremely low following ALA-enriched egg consumption (Ferrier et al., 1992; Ferrier et al., 1995).

The above described effects are expected to have an overall favorable influence on the risk of cardiovascular disease. Importantly, it has been suggested that the majority of the positive effects is related to presence of DHA in the eggs, rather than ALA (Ferrier et al., 1992; Ferrier et al., 1995).

Additionally, Cherian and Sim (1996) showed that feeding ALAenriched eggs to nursing women resulted in enrichment of breast milk with ALA and DHA.

\section{Fish oil}

Supplementation with flaxseed results in a strong increase in ALA. Unfortunately, as discussed in the introduction, this is the least interesting $\mathrm{n}-3$ PUFA as its health benefits are limited, and its conversion into EPA and DHA is quite inefficient. EPA + DHA levels in the above described eggs are generally below $100 \mathrm{mg} / \mathrm{egg}$. Therefore, direct supplementation with a dietary source rich in EPA and/or DHA may be a more interesting route.

$\mathrm{N}-3$ PUFA enriched eggs produced through feed supplementation with fish oil, often in combination with flaxseed, are commercially available. The following section discusses enrichment of hen eggs through feed supplementation with fish oil.

\subsection{Production parameters and egg quality characteristics}

Similar as described in Section 2.1 for supplementation with oilseeds, contradicting results on the influence of fish oil supplementation on hens' production parameters have been published. Several authors reported impaired production parameters, especially a decrease in egg and/or yolk weight upon feeding fish oil (Gonzalez-Esquerra \& Leeson, 2000; Lawlor, Gaudette, Dickson, \& House, 2010; Van Elswyk, Hargis, Williams, \& Hargis, 1994). It has been suggested that long chain $n-3$ PUFA consumption causes a decrease in serum triglycerides in the hens, hence a decrease in amount of lipids available for yolk formation (Van Elswyk et al., 1994). Furthermore, n-3 PUFA may influence circulating estradiol, affecting liver lipid metabolism. In addition, in some cases the lower egg weight may relate to the fact that less feed is being consumed (Gonzalez-Esquerra \& Leeson, 2000). Several other authors, however, did not observe an effect on egg weight (Cachaldora, GariaRebollar, Alvarez, Mendez, \& De Blas, 2008; Carrillo et al., 2008) or feed intake (Aymond \& Van Elswyk, 1995; Herber \& Van Elswyk, 1996).

\section{2. $N-3$ PUFA in eggs}

Although fish oil contains EPA as well as DHA, eggs from hens fed fish oil are mostly enriched with DHA, while EPA contents increase to a much lesser extent (see Table 1, (Bovet, Faeh, Madeleine, Viswanathan, \& Paccaud, 2007; Cachaldora, Garia-Rebollar, Alvarez, Mendez, \& De Blas, 2008; Carrillo et al., 2008; Farrell, 1998; Gonzalez-Esquerra \& Leeson, 2000; Lawlor et al., 2010; Van Elswyk et al., 1995)), suggesting that DHA might be preferentially incorporated into membranes in comparison with EPA (Herber \& Van Elswyk, 1996).

Cachaldora, Garia-Rebollar, Alvarez, Mendez, and De Blas (2008) compared addition of EPA-rich fish oil with addition of DHA-rich fish oil. For both treatments, the major $\mathrm{n}-3$ PUFA in eggs was DHA, accompanied by small amounts of EPA (see Table 1). Interestingly, it 
was calculated that the proportion of ingested long chain $n-3$ PUFA (EPA + DHA) that was deposited in yolk fat (in the form of DHA) did not differ significantly between both diets. Their results indicate that dietary EPA is largely converted to DHA. The efficiency of this conversion is only slightly lower than that of direct deposition of dietary DHA in yolk.

With increasing levels of fish oil addition, the increase in yolk DHA content was not proportional indicating a lower deposition efficiency at higher inclusion levels (see Table 1, (Cachaldora, De Blas, Garia-Rebollar, Alvarez, \& Mendez, 2005; Cachaldora, Garia-Rebollar, Alvarez, Mendez, \& De Blas, 2008; Gonzalez-Esquerra \& Leeson, 2000; Lawlor et al., 2010; Van Elswyk et al., 1995)). It has been shown that EPA and DHA are preferentially incorporated in phospholipids (Fredriksson et al., 2006; Jiang et al., 1991). The fact that phospholipids are structural lipids, may account for the limited deposition efficiency (Cachaldora, Garia-Rebollar, Alvarez, Mendez, \& De Blas, 2008).

Similar as to what has been discussed in Section 2.2 for ALAenriched eggs, the increase in $n-3$ PUFA upon fish oil supplementation is accompanied by a decrease in AA and total $n-6$ PUFA (Cachaldora, Garia-Rebollar, Alvarez, Mendez, \& De Blas, 2008; Poureslami et al., 2012; Van Elswyk et al., 1995), while yolk cholesterol content remains unaffected (Rizzi et al., 2009; Scheideler \& Froning, 1996).

\subsection{Oxidative stability and sensorial characteristics}

Long chain $n-3$ PUFA (EPA and DHA) contain more double bonds than ALA. As a result, they are even more susceptible to oxidative breakdown. Inclusion levels above $1.5 \%$ of fish oil generate eggs which are generally unacceptable to western consumers (Gonzalez-Esquerra \& Leeson, 2000; Gonzalez-Esquerra \& Leeson, 2001). Sensory panels typically described the taste of these eggs as "fishy". This fishy taste paralleled the amount of $n-3$ PUFA in the eggs (Van Elswyk et al., 1995). Van Elswyk et al. (1995) analyzed headspace volatiles in eggs from hens fed menhaden oil and found an increase in volatile compounds of low molecular weight. Unfortunately, dietary inclusion of fish oil at levels around 1.5\% (threshold level for off-flavors) generally results in yolk DHA levels below $100 \mathrm{mg} / \mathrm{egg}$ (Aymond \& Van Elswyk, 1995; Gonzalez-Esquerra \& Leeson, 2000; Lawlor et al., 2010), although a somewhat higher value (138 mg/egg) has been reported as well (Herber \& Van Elswyk, 1996). These levels are not much higher than those produced through dietary supplementation with flaxseed, as described in Section 2.2.

As discussed in Section 2.3, oxidative damage in egg yolks is caused by direct deposition of oxidized lipids from the feed. Therefore, in order to overcome sensorial hurdles, the use of high quality oil is often recommended. However, Gonzalez-Esquerra and Leeson (2000) observed that deodorization of menhaden oil in order to reduce the amount of volatiles in the hens' feed did not improve the acceptability of eggs. Similarly, feed supplementation with microencapsulated fish oil, which is expected to have a greater oxidative stability, still had a negative impact on egg sensory attributes (Lawlor et al., 2010).

\subsection{Health related aspects of eggs}

Several authors reported an increase in DHA levels in the serum of human subjects who consumed eggs from hens fed fish oil. For example, this effect was observed by Oh, Ryue, Hsieh, and Bell (1991), upon consumption of 28 enriched eggs (from hens fed 10\% fish oil) per week during 4 weeks by healthy volunteers; by Farrell (1998) who studied healthy volunteers consuming 7 enriched eggs (from hens fed $2 \%$ to $5 \%$ fish oil) per week for 22 weeks and by Gillingham, Caston, Leeson, Hourtovenko, and Holub (2005) who fed 14 eggs (from hens fed a combination of flaxseed and menhaden oil) per week for 6 weeks to statin-treated hypercholesterolemic patients.

In addition, Oh et al. (1991) found a significant decrease in serum triglyceride level in healthy volunteers who consumed 28 enriched eggs (from hens fed 10\% fish oil) per week. Similar observations were made by Bovet et al. (2007).

Similar as for ALA-enriched eggs, these effects probably have a favorable effect on the risk of cardiovascular disease.

\section{Heterotrophic microalgae}

Several types of microalgae are rich in $n-3$ PUFA, especially EPA and DHA. Specifically, in the quest for $n-3$ PUFA-rich sources, technology has been developed to produce marine microalgae with an extremely high DHA content ( $\pm 18 \%$ of dry mass) via a fermentation process (Barclay, Meager, \& Abril, 1994). Whether or not these organisms should be regarded as algae is debatable, since "algae" specifically refers to autotrophic organisms (Barsanti \& Gualtier, 2006). We will refer to these species as "heterotrophic microalgae (HMA)". Several HMA products are commercially available, in the form of whole biomass as well as extracted oil.

During the last 15 years, a number of research groups started investigating the possibility of adding HMA to hens' feed as a means to enrich eggs in $n-3$ PUFA. Today, such eggs are available on the market in several countries, and their share is expected to grow as the market for functional foods is still expanding (Surai \& Sparks, 2001).

\subsection{Production parameters and egg quality characteristics}

Little is known about zootechnical performance of hens fed HMA. As discussed in Sections 2.1 and 3.1 for flaxseed and fish oil, results are often contradicting, and no clear explanation can be found for the observed discrepancies. Probably, above described parameters such as hens' strain, age, basal feed and feed formulation affect the outcome of each individual experiment.

Rizzi et al. (2009) supplemented the feed of 28-week old hens with $1.67 \%$ of HMA. They observed a small increase in feed intake and an increase in egg weight relative to eggs from hens fed an isocaloric control diet. Tallarico et al. (2002) perceived no change in egg weight upon addition of $2 \%$ of HMA, while Herber and Van Elswyk (1996) observed a transient depression in egg weight from 24-week-old hens fed 4.8\% HMA. The latter was not seen in a similar experiment with 52-week-old hens, suggesting that the reproductive maturity may influence the response to $n-3$ PUFA rich feed.

Dietary supplementation with DHA-rich oil extracted from HMA was not found to affect egg weight or production (Cachaldora, GariaRebollar, Alvarez, Mendez, \& De Blas, 2008; Cachaldora et al., 2005; Cheng, Shen, Chen, \& Ding, 2004).

\section{2. $N-3$ PUFA in eggs}

Eggs from hens fed HMA (rich in DHA, little or no EPA) typically show similar PUFA profiles as eggs from hens fed fish oil: their DHA content strongly increases (see Table 1, (Cachaldora et al., 2005; Cachaldora, Garia-Rebollar, Alvarez, Mendez, \& De Blas, 2008; Cheng et al., 2004; Herber \& Van Elswyk, 1996; Meluzzi, Sirri, Tallarico, \& Franchini, 2001; Rizzi et al., 2009)) at the expense of n-6 PUFA (Cachaldora, Garia-Rebollar, Alvarez, Mendez, \& De Blas, 2008; Herber \& Van Elswyk, 1996; Rizzi et al., 2009). Herber and Van Elswyk (1996) compared addition of $1.5 \%$ menhaden oil (EPA + DHA) with addition of 2.4 or $4.8 \%$ HMA (DHA). From the first week of supplementation on, egg DHA enrichment was observed. 1.5\% menhaden oil and 2.4\% HMA treatments resulted in similar DHA deposition, even though $1.5 \%$ menhaden oil comprised higher amounts of $n-3$ PUFA. As discussed in Section 3.2, direct deposition of DHA is slightly more efficient than conversion of EPA to DHA.

As described in Section 3.2 for fish oil supplementation, the efficiency of DHA incorporation depends on the dietary concentration. At low levels of DHA in the feed, efficiencies up to 50\% have been reported (Gonzalez-Esquerra \& Leeson, 2001), but the retention 
efficiency decreases greatly at higher supplementation levels (see Table 1, (Cachaldora et al., 2005; Cachaldora, Garia-Rebollar, Alvarez, Mendez, \& De Blas, 2008; Cheng et al., 2004; Herber \& Van Elswyk, 1996)).

Similar as addition of flaxseed or fish oil, feed supplementation with heterotrophic algae does not affect the yolk cholesterol content (Rizzi et al., 2009).

\subsection{Carotenoids in eggs}

HMA contain several carotenoids, of which $\beta$-carotene and canthaxanthin are the most abundant (Herber-McNeill \& Van Elswyk, 1998). A shift in yolk color towards red was observed in eggs from hens fed HMA (Tallarico et al., 2002), reaching a plateau within 2 weeks (HerberMcNeill \& Van Elswyk, 1998). This suggests that carotenoids have been transferred to egg yolks. It is generally recognized that $\beta$-carotene is hardly deposited in yolk because hens possess enzymes to convert $\beta$-carotene efficiently to vitamin A. Other carotenoids such as canthaxanthin are transferred more efficiently (Herber-McNeill \& Van Elswyk, 1998; National Research Council, 1994; Schlatterer \& Breithaupt, 2006). Carotenoids can offer several advantages, since they act as antioxidants, providing health benefits and increasing the oxidative stability of yolk lipids. On the other hand, consumer acceptance of a reddish yolk color varies between geographical regions. In Europe, for example, consumers in northern countries prefer pale yolks, while in the south, dark-yellow, reddish yolks are preferred.

\subsection{Oxidative stability and sensorial characteristics}

Herber-McNeill and Van Elswyk (1998) served scrambled eggs from hens fed $2.4 \%$ and $4.8 \%$ of HMA to an untrained consumer panel. No significant differences were found with respect to control eggs. This finding is surprising, since the $n-3$ PUFA levels were quite high, especially in the eggs resulting from 4.8\% HMA addition (DHA content of $11.5 \mathrm{mg} / \mathrm{g}$ yolk, assuming a yolk content of $17 \mathrm{~g}$ per egg, the egg would contain 196 mg of DHA) (Herber-McNeill \& Van Elswyk, 1998). Likewise, Parpinello, Meluzzi, Sirri, Tallarico, and Versari (2006) reported that eggs produced through feed supplementation with $2 \%$ HMA were of good sensorial quality. The presence of carotenoids which can act as antioxidants, and the fact that the lipids are located inside cells, providing a natural means of encapsulation, may enhance the oxidative stability of lipids in the eggs, contributing to their good sensorial characteristics.

When oil extracted from HMA was added to hens' feed, the acceptability of hard-boiled eggs strongly decreased (Cachaldora, Garia-Rebollar, Alvarez, Mendez, \& De Blas, 2008). Upon extraction, oil is exposed to oxygen, which probably decreases lipid stability. In addition, carotenoids may be lost during extraction and refining (Cachaldora, Garia-Rebollar, Alvarez, Mendez, \& De Blas, 2008).

\subsection{Health related aspects of eggs}

Maki et al. (2003) studied lipid responses in mildly hypertriglyceridemic men and women upon weekly consumption of 10 regular eggs vs. eggs enriched in DHA content through addition of HMA. Consumption of DHA-enriched eggs for 6 weeks induced a $41 \%$ increase in DHA serum levels. Specifically, in subjects with body mass index $\geq 30 \mathrm{~kg} / \mathrm{m}^{2}$, the DHA treatment resulted in a larger reduction in serum triglyceride levels and a greater increase in HDL cholesterol in comparison with regular eggs, suggesting a favorable health effect.

\section{Autotrophic microalgae}

In addition to the above discussed "heterotrophic microalgae", many autotrophic microalgae also produce high amounts of long chain $n-3$ PUFA. In addition, they are often very rich in carotenoids, since carotenoids are essential constituents of the photosynthetic apparatus (Cardozo et al., 2007; Plaza, Herrero, Cifuentes, \& Ibanez, 2009). Today, the high price of autotrophic $n-3$ PUFA producing microalgae restricts their application in the production of relatively low-value products such as eggs. Production costs are mainly related to cultivation and harvesting. Fortunately, continuous effort is being done by engineers and scientists to develop cost-effective technologies, which should enhance the economical feasibility in the near future (Oilgae Report Academic Edition, 2011).

Very little is known about addition of autotrophic microalgae to hens' feed. In three studies, Nannochloropsis species (Heterokontophyta) have been supplemented to hens' diet (Foubert, Bruneel, Fraeye, Muylaert, \& Buyse, 2011; Fredriksson et al., 2006; Nitsan, Mokady, \& Sukenik, 1999).

Nitsan et al. (1999) observed no change in egg production rate or egg weight upon addition of $1 \%$ Nannochloropsis sp. or $1 \%$ lipid extract from this microalga. Furthermore, no significant change in hen body weight, feed intake, egg production rate or egg weight was observed by Foubert et al. (2011) upon supplementation with $5 \%$ or $10 \%$ Nannochloropsis gaditana.

The Nannochloropsis species used by Nitsan et al. (1999) had an interesting fatty acid profile, as it had a high EPA content while other n-3 PUFA were largely absent. This specific lipid composition allowed to study the metabolism of dietary EPA in laying hens. It was observed that EPA did not accumulate in egg yolk. It was largely converted to DHA and deposited in liver and egg yolk. The efficiency of EPA into DHA conversion was estimated to be considerably better than that of ALA to DHA, as was also discussed above in Section 3.2.

Fredriksson et al. (2006) added Nannochloropsis oculata, a species containing both EPA and ALA, to hens' feed. Beside low concentrations of EPA, they also found significant accumulation of DHA in egg yolk (see Table 1), especially in the phospholipid fraction, at the expense of n-6 PUFA (Fredriksson et al., 2006). Similar results were obtained in the study of Foubert et al. (2011) using N. gaditana (see Table 1).

In addition to $n-3$ PUFA, Nannochloropsis contains high amounts of vitamin E and various carotenoids, which can help prevent lipid oxidation. Carotenoid content of egg yolks increased significantly (Fredriksson et al., 2006), which influenced yolk color dramatically (Foubert et al., 2011; Fredriksson et al., 2006; Nitsan et al., 1999). Similarly, upon addition of Porphyridium sp. (Rodophyta) to hens' diet, Ginzberg et al. (2000) noted a shift in yolk color to darker yellow, which was caused by an increase in yolk carotenoid content.

To our knowledge, no reports on oxidative stability, sensorial characteristics or health related aspects of eggs from hens fed autotrophic microalgae rich in $n-3$ PUFA have been published.

\section{Conclusion and perspectives}

The health promoting effects of $n-3$ PUFA can mainly be ascribed to EPA and DHA. Given the relatively limited conversion of ALA into EPA and DHA (by humans, as well as by laying hens), feed supplementation with long chain $n-3$ fatty acids in the form of fish oil or microalgae, is much more interesting compared to supplementation with their precursor ALA through addition of flaxseed. While addition of high doses of fish oil can lead to relatively high amounts of DHA in eggs, the dose needs to be restricted due to sensorial hurdles, mainly caused by oxidized $n-3$ PUFA in eggs.

Addition of microalgae as a source of long chain $n-3$ PUFA to hens' diet is an effective way to increase the DHA level in eggs. Furthermore, this approach offers several advantages in comparison with fish oil, especially with regard to oxidative stability of lipids. Today, "heterotrophic microalgae" are being added to laying hens' feed, yielding eggs with DHA contents up to $200 \mathrm{mg}$ per egg, while maintaining consumer acceptability. Such eggs are available on the market in several countries. Use of autotrophic microalgae may even offer additional advantages, relating to their higher carotenoid content. 
However, their price is currently too high. Furthermore, little research has been done and only Nannochloropsis sp. have been studied. More information is needed on the efficiency of EPA into DHA conversion, as well as on digestibility of the microalgal cell walls. In addition, it would be interesting to study other $n-3$ PUFA-rich autotrophic microalgae species.

Comparison between the different $\mathrm{n}-3$ rich feed supplements is not always straightforward, since numerous experimental factors (hen's strain and age, basal feed, feed formulation, ...) affect the outcome. Therefore, it seems interesting to conduct a single study in which all relevant n-3 PUFA sources (flaxseed, fish oil, HMA, autotrophic algae) are compared with respect to their effect on production parameters, egg characteristics, egg $n-3$ PUFA content and lipid oxidative stability.

However, even with such an approach, questions will remain on the efficiency by which ALA, EPA or DHA from feed are converted and deposited in the eggs. This mainly depends on the amount of $n-3$ PUFA added and the lipid composition of basal feed and supplement (LA-ALA-EPA-DHA ratios). With the traditional $\mathrm{n}-3$ PUFA sources, it is difficult to assess these individual effects unequivocally, since these sources differ in several parameters (e.g. bioaccessibility of $n-3$ PUFA, metabolizable energy, $n-6$ PUFA content, ...) which will affect the outcome. In order to quantify the efficiency of $n-3$ PUFA conversion and transfer to the eggs correctly, the best experimental approach would be to supplement feed with pure oils, containing only ALA, EPA or DHA, in varying amounts, whether or not in combination with LA. This would allow to gain fundamental insight in the respective conversion and deposition efficiencies. Unfortunately, price and availability of pure oils may impede such experiment.

\section{Acknowledgment}

This work was supported by Flanders' FOOD (project Omega-EI).

I. Fr. is a Postdoctoral Researcher funded by the Research Foundation - Flanders (FWO).

\section{References}

European Food Safety Authority (2010). Scientific opinion on the substantiation of health claims related to eicosapentaenoic acid (EPA), docosahexaenoic acid (DHA), docosapentaenoic acid (DPA) and maintenance of normal cardiac function, maintenance of normal blood glucose concentrations, maintenance of normal blood pressure, maintenance of normal blood HDL-cholesterol concentrations, maintenance of normal (fasting) blood concentrations of triglycerides, maintenance of normal blood LDL-cholesterol concentrations, protection of the skin from photo-oxidative (UV-induced) damage, improved absorption of EPA and DHA, contribution to the normal function of the immune system by decreasing the levels of eicosanoids, arachidonic acid-derived mediators and pro-inflammatory cytokines, and "immunomodulating agent" pursuant to Article 13(1) of Regulation (EC) No 1924/2006. The EFSA Journal, 8, 1796.

Aymond, W. M., \& Van Elswyk, M. E. (1995). Yolk thiobarbituric acid reactive substances and $\mathrm{n}-3$ fatty-acids in response to whole and ground flaxseed. Poultry Science, 74, 1388-1394.

Barclay, W. R., Meager, K. M., \& Abril, J. R. (1994). Heterotrophic production of longchain omega-3-fatty-acids utilizing algae and algae-like microorganisms. Journal of Applied Phycology, 6, 123-129.

Barsanti, L., \& Gualtier, P. (2006). Algae. anatomy, biochemistry and biotechnology. CRC Taylor \& Francis.

Baucells, M. D., Crespo, N., Barroeta, A. C., Lopez-Ferrer, S., \& Grashorn, M. A. (2000). Incorporation of different polyunsaturated fatty acids into eggs. Poultry Science, 79, 51-59.

Bean, L. D., \& Leeson, S. (2002). Metabolizable energy of layer diets containing regular or heat-treated flaxseed. Journal of Applied Poultry Research, 11, 424-429.

Bean, L. D., \& Leeson, S. (2003). Long-term effects of feeding flaxseed on performance and egg fatty acid composition of brown and white hens. Poultry Science, 82, 388-394.

Bovet, P., Faeh, D., Madeleine, G., Viswanathan, B., \& Paccaud, F. (2007). Decrease in blood triglycerides associated with the consumption of eggs of hens fed with food supplemented with fish oil. Nutrition, Metabolism, and Cardiovascular Diseases, 17.

Burdge, G. (2004). Alpha-linolenic acid metabolism in men and women: Nutritional and biological implications. Current Opinion in Clinical Nutrition and Metabolic Care, 7, 137-144.

Cachaldora, P., De Blas, J. C., Garia-Rebollar, P., Alvarez, C., \& Mendez, J. (2005). Short communication. Effects of type and level of supplementation with dietary $n-3$ fatty acids on yolk fat composition and $n-3$ fatty acid retention in hen eggs. Spanish Journal of Agricultural Research, 3, 209-212.

Cachaldora, P., Garcia-Rebollar, P., Alvarez, C., De Blas, J. C., \& Mendez, J. (2008). Effect of type and level of basal fat and level of fish oil supplementation on yolk fat composition and $\mathrm{n}-3$ fatty acids deposition efficiency in laying hens. Animal Feed Science and Technology, 141, 104-114.

Cachaldora, P., Garia-Rebollar, P., Alvarez, C., Mendez, J., \& De Blas, J. C. (2008). Double enrichment of chicken eggs with conjugated linoleic acid and $n-3$ fatty acids through dietary fat supplementation. Animal Feed Science and Technology, 144 315-326.

Cardozo, K. H. M., Guaratini, T., Barros, M. P., Falcao, V. R., Tonon, A. P., Lopes, N. P., et al. (2007). Metabolites from algae with economical impact. Comparative Biochemistry and Physiology - Part C: Toxicology \& Pharmacology, 146, 60-78.

Carrillo, S., Lopez, E., Casas, M. M., Avila, E., Castillo, R. M., Carranco, M. E., et al. (2008) Potential use of seaweeds in the laying hen ration to improve the quality of $n-3$ fatty acid enriched eggs. Journal of Applied Phycology, 20, 721-728.

Caston, L. J., Squires, E. J., \& Leeson, S. (1994). Hen performance, egg quality, and the sensory evaluation of eggs from Scwl hens fed dietary flax. Canadian Journal of Animal Science, 74, 347-353.

Cheng, C. H., Shen, T. F., Chen, W. L., \& Ding, S. T. (2004). Effects of dietary algal docosahexaenoic acid oil supplementation on fatty acid deposition and gene expression in laying Leghorn hens. Journal of Agricultural Science, 142, 683-690.

Cherian, G., \& Sim, J. S. (1996). Changes in the breast milk fatty acids and plasma lipids of nursing mothers following consumption of $n-3$ polyunsaturated fatty acid enriched eggs. Nutrition, 12.

Cottin, S. C., Sanders, T. A., \& Hall, W. L. (2011). The differential effects of EPA and DHA on cardiovascular risk factors. Proceedings of the Nutrition Society, 70, 215-231.

Domingo, J. L., \& Bocio, A. (2007). Levels of PCDD/PCDFs and PCBs in edible marine species and human intake: A literature review. Environment International, 33, 397-405.

Farrell, D. J. (1998). Enrichment of hen eggs with $n-3$ long-chain fatty acids and evaluation of enriched eggs in humans. American Journal of Clinical Nutrition, 68.

Ferrier, L., Caston, L., Leeson, S., Jamessquires, E., Celi, B., Thomas, L., et al. (1992). Changes in serum lipids and platelet fatty acid composition following consumption of eggs enriched in alpha-linolenic acid (LnA). Food Research International, 25.

Ferrier, L. K., Caston, L. J., Leeson, S., Squires, J., Weaver, B. J., \& Holub, B. J. (1995) Alpha-linolenic acid-and docosahexaenoic acid-enriched eggs from hens fed flaxseed: Influence on blood lipids and platelet phospholipid fatty acids in humans. American Journal of Clinical Nutrition, 62.

Foubert, I., Bruneel, C., Fraeye, I., Muylaert, K., \& Buyse, J. (2011). Effect of algal feed supplement on omega 3 enrichment in eggs. Poster presentation at the 4 th congress of the international society for applied phycology, June 19-24, Halifax, Canada.

Fredriksson, S., Elwinger, K., \& Pickova, J. (2006). Fatty acid and carotenoid composition of egg yolk as an effect of microalgae addition to feed formula for laying hens. Food Chemistry, 99, 530-537.

Galobart, J., Barroeta, A. C., Baucells, M. D., Cortinas, L., \& Guardiola, F. (2001). Alpha-tocopherol transfer efficiency and lipid oxidation in fresh and spraydried eggs enriched with omega 3-polyunsaturated fatty acids. Poultry Science, 80, 1496-1505.

Gillingham, L., Caston, L., Leeson, S., Hourtovenko, K., \& Holub, B. (2005). The effects of consuming docosahexaenoic acid (DHA)-enriched eggs on serum lipids and fatty acid compositions in statin-treated hypercholesterolemic male patients. Food Research International, 38.

Ginzberg, A., Cohen, M., Sod-Moriah, U. A., Shany, S., Rosenshtrauch, A., \& Arad, S (2000). Chickens fed with biomass of the red microalga Porphyridium sp have reduced blood cholesterol level and modified fatty acid composition in egg yolk. Journal of Applied Phycology, 12, 325-330.

Gonzalez-Esquerra, R., \& Leeson, S. (2000). Effect of feeding hens regular or deodorized menhaden oil on production parameters, yolk fatty acid profile, and sensory quality of eggs. Poultry Science, 79, 1597-1602.

Gonzalez-Esquerra, R., \& Leeson, S. (2001). Alternatives for enrichment of eggs and chicken meat with omega-3 fatty acids. Canadian Journal of Animal Science, 81 295-305.

Harris, W. S., Mozaffarian, D., Lefevre, M., Toner, C. D., Colombo, J., Cunnane, S. C., et al (2009). Towards establishing dietary reference intakes for eicosapentaenoic and docosahexaenoic acids. Journal of Nutrition, 139, 804S-819S.

Hayat, Z., Cherian, G., Pasha, T. N., Khattak, F. M., \& Jabbar, M. A. (2009). Effect of feeding flax and two types of antioxidants on egg production, egg quality, and lipid composition of eggs. Journal of Applied Poultry Research, 18, 541-551.

Hayat, Z., Cherian, G., Pasha, T. N., Khattak, F. M., \& Jabbar, M. A. (2010). Oxidative stability and lipid components of eggs from flax-fed hens: Effect of dietary antioxidants and storage. Poultry Science, 89, 1285-1292.

Hayat, Z., Cherian, G., Pasha, T. N., Khattak, F. M., \& Jabbar, M. A. (2010). Sensory evaluation and consumer acceptance of eggs from hens fed flax seed and 2 different antioxidants. Poultry Science, 89, 2293-2298.

Herber, S. M., \& Van Elswyk, M. E. (1996). Dietary marine algae promotes efficient deposition of $n-3$ fatty acids for the production of enriched shell eggs. Poultry Science, 75, 1501-1507.

Herber-McNeill, S. M., \& Van Elswyk, M. E. (1998). Dietary marine algae maintains egg consumer acceptability while enhancing yolk color. Poultry Science, 77, 493-496.

Jiang, Z., Ahn, D. U., \& Sim, J. S. (1991). Effects of feeding flax and 2 types of sunflower seeds on fatty-acid compositions of yolk lipid classes. Poultry Science, 70, 2467-2475.

Jiang, Z. R., \& Sim, J. S. (1993). Consumption of $n-3$ polyunsaturated fatty acid-enriched eggs and changes in plasma-lipids of human-subjects. Nutrition, 9, 513-518.

Jordan, R. G. (2010). Prenatal omega-3 fatty acids: Review and recommendations. Journal of Midwifery E' Women's Health, 55, 520-528. 
Kromhout, D., Giltay, E. J., \& Geleijnse, J. M. (2010). n-3 fatty acids and cardiovascular events after myocardial infarction. The New England Journal of Medicine, 363, 2015-2026.

Lawlor, J. B., Gaudette, N., Dickson, T., \& House, J. D. (2010). Fatty acid profile and sensory characteristics of table eggs from laying hens fed diets containing microencapsulated fish oil. Animal Feed Science and Technology, 156, 97-103.

Leeson, S., Caston, L., \& MacLaurin, T. (1998). Organoleptic evaluation of eggs produced by laying hens fed diets containing graded levels of flaxseed and vitamin E. Poultry Science, 77, 1436-1440.

Lewis, N. M., Schalch, K., \& Scheideler, S. E. (2000). Serum lipid response to $n-3$ fatty acid enriched eggs in persons with hypercholesterolemia. Journal of the American Dietetic Association, 100

Maki, K. C., Van Elswyk, M. E., McCarthy, D., Seeley, M. A., Veith, P. E., Hess, S. P., et al. (2003). Lipid responses in mildly hypertriglyceridemic men and women to consumption of docosahexaenoic acid-enriched eggs. International Journal for Vitamin and Nutrition Research, 73, 357-368.

Meluzzi, A., Sirri, F., Tallarico, N., \& Franchini, A. (2001). Effect of different vegetable lipid sources on the fatty acid composition of egg yolk and on hen performance. Archiv fur Geflugelkunde, 65, 207-213.

Molendi-Coste, O., Legry, V., \& Leclercq, I. A. (2011). Why and how meet n-3 PUFA Dietary Recommendations? Gastroenterology Research and Practice. doi:10.1155/2011/364040

National Research Council (1994). Nutrient requirements of poultry (9th edition). Washington, DC: National Academy Press.

Nitsan, Z., Mokady, S., \& Sukenik, A. (1999). Enrichment of poultry products with omega 3 patty acids by dietary supplementation with the alga Nannochloropsis and mantur oil. Journal of Agricultural and Food Chemistry, 47, 5127-5132.

Oh, S. Y., Ryue, J., Hsieh, C. H., \& Bell, D. E. (1991). Eggs enriched in omega-3 fatty acids and alterations in lipid concentrations in plasma and lipoproteins and in blood pressure. American Journal of Clinical Nutrition, 54.

Parpinello, G. P., Meluzzi, A., Sirri, F., Tallarico, N., \& Versari, A. (2006). Sensory evaluation of egg products and eggs laid from hens fed diets with different fatty acid composition and supplemented with antioxidants. Food Research International, 39, 47-52.

Plaza, M., Herrero, M., Cifuentes, A., \& Ibanez, E. (2009). Innovative natural functional ingredients from microalgae. Journal of Agricultural and Food Chemistry, 57, 7159-7170.

Poureslami, R., Raes, K., Huyghebaert, G., Batal, A. B. \& De Smet, S. (2012). Egg yolk fatty acid profile in relation to dietary fatty acid concentrations. Journal of the Science of Food and Agriculture, 92, 366-372.

Poureslami, R., Raes, K., Turchini, G. M., Huyghebaert, G., \& De Smet, S. (2010). Effect of diet, sex and age on fatty acid metabolism in broiler chickens: $n-3$ and $n-6$ PUFA British Journal of Nutrition, 104, 189-197.

Qi, B. X., Fraser, T., Mugford, S., Dobson, G., Sayanova, O., Butler, J., et al. (2004). Production of very long chain polyunsaturated omega-3 and omega- 6 fatty acids in plants. Nature Biotechnology, 22, 739-745.
Oilgae Report Academic Edition (2011). www.oilgae.com. On-line available: www.oilgae.com

Rizzi, L., Bochicchio, D., Bargellini, A., Parazza, P., \& Simioli, M. (2009). Effects of dietary microalgae, other lipid sources, inorganic selenium and iodine on yolk $n-3$ fatty acid composition, selenium content and quality of eggs in laying hens. Journal of the Science of Food and Agriculture, 89, 1775-1781.

Scheideler, S. E., \& Froning, G. W. (1996). The combined influence of dietary flaxseed variety, level, form, and storage conditions on egg production and composition among vitamin E-supplemented hens. Poultry Science, 75, 1221-1226.

Scheideler, S. E., Froning, G., \& Cuppett, S. (1997). Studies of consumer acceptance of high omega-3 fatty acid-enriched eggs. Journal of Applied Poultry Research, 6, 137-146.

Scheideler, S. E., Jaroni, D., \& Froning, G. (1998). Strain and age effects on egg composition from hens fed diets rich in n-3 fatty acids. Poultry Science, 77, 192-196.

Schlatterer, J., \& Breithaupt, D. E. (2006). Xanthophylls in commercial egg yolks: Quantification and identification by HPLC and LC-(APCI)MS using a C30 phase. Journal of Agricultural and Food Chemistry, 54, 2267-2273.

Sioen, I. A., Pynaert, I., Matthys, C., De Backer, G., Van Camp, J., \& De Henauw, S. (2006). Dietary intakes and food sources of fatty acids for Belgian women, focused on n-6 and $n-3$ polyunsaturated fatty acids. Lipids, 41, 415-422.

Surai, P. F., \& Sparks, N. H. C. (2001). Designer eggs: From improvement of egg composition to functional food. Trends in Food Science and Technology, 12, 7-16.

Tallarico, N., Sirri, F., Meluzzi, A., Pittia, P., Parpinello, G. P., \& Franchini, A. (2002). Effect of dietary vegetable lipids on functional and sensory properties of chicken eggs. Italian Journal of Food Science, 14, 159-166.

Trautwein, E. A. (2001). N-3 fatty acids - Physiological and technical aspects for their use in food. European Journal of Lipid Science and Technology, 103, 45-55.

Van Elswyk, M. E., Dawson, P. L., \& Sams, A. R. (1995). Dietary menhaden oil influences sensory characteristics and headspace volatiles of shell eggs. Journal of Food Science, $60,85-89$.

Van Elswyk, M. E., Hargis, B. M., Williams, J. D., \& Hargis, P. S. (1994). Dietary menhaden oil contributes to hepatic lipidosis in laying hens. Poultry Science, 73, 653-662.

Welch, A. A., Shakya-Shrestha, S., Lentjes, M. A. H., Wareham, N. J., \& Khaw, K. T. (2011). Dietary intake and status of $n-3$ polyunsaturated fatty acids in a population of fish-eating and non-fish-eating meat eaters, vegetarians, and vegans and the precursor-product ratio of alpha-linolenic acid to long-chain $n-3$ polyunsaturated fatty acids: Results from the EPIC-Norfolk cohort (vol 92, pg 1040, 2010). American Journal of Clinical Nutrition, 93, 676.

Yashodhara, B. M., Umakanth, S., Pappachan, J. M., Bhat, S. K., Kamath, R., \& Choo, B. H. (2009). Omega-3 fatty acids: A comprehensive review of their role in health and disease. Postgraduate Medical Journal, 85, 84-90. 